\author{
원전 증기발생기 전열관의 확관방법에 따른 응력부식균열 \\ 저항성 연구 \\ 김용규 ${ }^{\dagger}$. 송명호 ${ }^{*}$ \\ 홍익대학교 재료공학부, "한국원자력안전기술원 \\ (2014년 4월 24일 접수, 2014년 5월 26일 수정, 2014년 5월 30일 채택)
}

\title{
A Study on the Resistance of Stress Corrosion Cracking due to Expansion Methods for Steam Generator Tubes in Nuclear Power Plants
}

\author{
Young Kyu $\mathrm{Kim}^{\dagger} \cdot$ Myung Ho Song ${ }^{*}$ \\ Hongik University, "Korea Institute of Nuclear Safety
}

(Received 24 April 2014, Revised 26 May 2014, Accepted 30 May 2014)

요약

원자력발전소의 증기발생기 전열관은 가동 중에 다양한 형태의 부식 손상이 발생한다. 전열관의 외면에 발생하는 응력부식균열은 2 차측 응력부식균열이라 불리는데 주로 전열관의 확관천이지역에서 발생한다. 그 원인은 이 지역의 기하학적 특성과 관련된 슬러지의 침적에 의한 불순물의 농축과 증기 발생기 제작과정에서 확관에 의한 잔류응력이다. 특히 잔류응력은 확관방법에 따라 방향성 및 그 크기 가 달라지는데 전열관에 발생하는 균열의 방향 및 발생빈도는 이와 관련이 있다. 현장 경험에 따르면, 폭발확관된 전열관은 수압확관된 전열관에 비해 확관천이 부위에서 원주방향 균열이 잘 발생하는 것 으로 나타났다. 따라서 본 연구에서는 예민화된 증기발생기 전열관에 대한 응력부식균열 시험을 통해 확관법에 따른 특정방향 균열의 발생빈도 및 균열 크기를 비교하였다. 또한 균열이 발생된 전열관의 파단면 검사를 통해 균열 양상과 수화학 환경 중의 특정 성분의 영향을 관찰하였다.

주요어 : 증기발생기 전열관, 입계응력부식균열, 확관천이부위, 폭발확관, 수압확관, 잔류응력

Abstract - The steam generator tubes of nuclear power plants have various types of corrosion failures during the plant operation. The stress corrosion cracking which occurs on the outer surface of tube is called the secondary side stress corrosion cracking and mainly occurs in the expansion-transition area of tube. The causes are the concentration of impurities by the sludge pile-up related to the geometry of its region and the residual stress by tube expansion in the process of steam generator manufacturing. Especially the directionality and sizes of residual stresses are differed according to the tube expansion methods and the direction and the frequency of tube cracks depend on their characteristics. In bases on the plant experiences, it is notified that circumferential cracks of tubes expanded with explosive expansion method are dominantly occurred compared to those of tubes done with hydraulic expansion one. Therefore in this study, according to tube expansion methods frequencies and sizes of tube cracks with specific direction are compared by means of accelerated immersion test and also the crack morphology and the specific chemicals from water-chemistry environment are observed through the fracture surface examination.

\footnotetext{
${ }^{\dagger}$ To whom corresponding should be addressed. Hongik University 2639 Sejongro Jochiwon-eup, Sejong-city, South 339-701 Korea

Tel : 044-860-2594 E-mail : kyu@hongik.ac.kr
} 
Key words : Steam Generator Tube, Intergranular Stress Corrosion Cracking, Explosive Expansion, Hydraulic Expansion, Expansion Transition Area, Residual Stress

1. 서 론

원자력발전소 증기발생기 전열관은 니켈기 합금인 Alloy 600 또는 Alloy 690을 사용하며 제작 시 전열 관을 관판에 고착시키기 위해 용접 및 확관과정을 거 친다. 국내 원전의 증기발생기 전열관은 관판 (tubesheet)에 전열관을 접합하는 방법으로 폭발확관 (explosive expansion) 그리고 수압확관(hydraulic expansion)이 적용되었으며 특히 한국표준형원전 (OPR-1000)에서는 폭발확관법이 그리고 그 이후의 원전에서는 수압확관법이 사용되었다[1]. 증기발생기 전열관은 발전소 가동 중에 다양한 형태의 부식손상 이 발생한다. 그 중 관판상단 부위인 확관천이지역에 서 발생하는 외면 응력부식균열을 2 차측 응력부식균 열(outer diameter stress corrosion cracking, $\mathrm{ODSCC}$ )이라 부른다. 2차측 응력부식균열은 균열발 생에 큰 영향을 미치는 부식 화학종에 대한 연구가 대부분이었으며, 잔류응력 등 응력에 의한 영향에 대 해서는 연구된 것이 많지 않다. 특히 균열의 방향이 원주방향일 경우, 이 균열형태는 증기발생기 전열관 의 건전성에 큰 위해가 된다. 원주방향 균열의 진전 에 따른 전열관 파단사고는 원전의 안전성을 위협하 는 대표적인 사고로 분류되어 왔다. 앞에서의 연구결 과에서 알 수 있듯이 전열관 확관방법 중 폭발확관된 전열관은 증기발생기 제작 당시부터 편심과 편향의 고유한 변형상태를 가지고 가동되며[2], 변형에 의한 국부적인 잔류응력의 집중과 편재(maldistribution)는 원주방향 균열의 우선 발생 및 성장을 유발시킬 것으 로 예상된다[3,4].

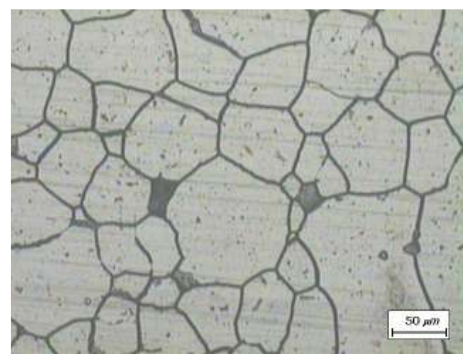

(a) Optical Micrography

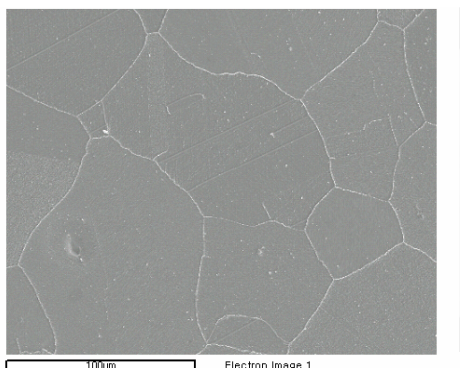

(b) SEM
따라서 확관에 의한 변형 및 잔류응력의 효과를 상 온에서 가속시험하기 위하여 Alloy 600 전열관 시편 을 예민화 처리하여 확관 이후의 응력부식균열 발생 여부를 확인하였다. 한편 균열이 발생된 전열관의 파 단면 검사를 통해 균열 양상을 관찰하였으며 수화학 환경 중의 어떤 성분이 응력부식균열의 발생에 영향 을 미쳤는지 조사하였다.

\section{2. 시편제작 및 실험방법}

\section{2-1. 시편제작}

Alloy 600 재료를 응력부식균열이 일어날 수 있도 록 $600^{\circ} \mathrm{C}$ 에서 24 시간 동안 예민화처리한 후 이 재료 를 사용하여 폭발 및 수압확관 방법으로 정상 및 과 확관된 시험편을 제작하였다. Fig. 1은 시편의 예민화 상태를 보여준다. 이들 확관 시험편은 그 상태로 부 식 시험을 수행할 수 없으므로 관판부위를 길이 50 $\mathrm{mm}$ 정도만 남기고 절단한 후, 관판을 $5 \mathrm{~mm}$ 정도 남 기고 증기발생기 세관과 동심이 되도록 봉상으로 가 공하였다. 절단 가공은 방전 가공 방법을 사용하여 잔류응력의 분포가 변화하지 않도록 주의하였으며, 가공하였을 때 확관시험편의 잔류응력의 분포에 미치 는 영향은 무시하였다. 이 시험편은 확관에 의한 천 이 영역에 대하여는 열처리 등의 과정에서 형성된 산 화물을 제거하기 위하여 $\mathrm{CW \#} 1000$ 정도의 사포지로 연마하였다. 또한 관판 재료는 2 가지를 준비하였는데 첫째, 스테인리스강 관판을 사용한 경우 Alloy 600 전열관과 스테인리스강 관판 사이의 갈바닉(galvanic coupling) 효과는 거의 없어 관판 몸체에 코팅을 하

Fig. 1. Microstructures of sensitized specimens at $600^{\circ} \mathrm{C}$ for 24 hours 


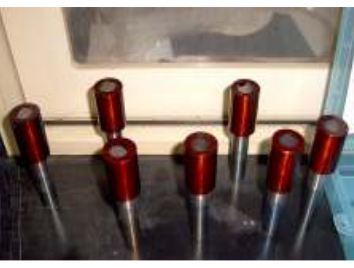

(a)

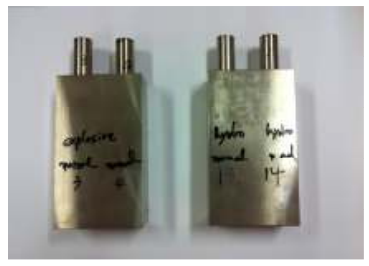

(b)
Fig. 2. Specimens used to be immersed into $0.1 \mathrm{M}$ $\mathrm{Na}_{2} \mathrm{~S}_{4} \mathrm{O}_{6}$ solution at room temperature: a) with SA 508 carbon steel tubesheet, b) with stainless steel tubesheet.

는 등의 용액 접촉방지 및 절연 처리는 필요 없었던 반면에 둘째, SA 508 탄소강 재료를 사용하는 경우 Alloy 600 세관과의 갈바닉 접촉 효과가 발생하지 않 도록 마이크로 스톱 (micro stop)이라는 에나멜을 코 팅하여 절연 처리하였다. Fig. 2는 관판의 길이를 적 절한 길이로 절단하기 전의 준비된 침지시험편의 모 양을 보여준다.

\section{2-2. 실험 방법}

실험에 사용한 용액은 $0.1 \quad \mathrm{M} \mathrm{Na}_{2} \mathrm{~S}_{4} \mathrm{O}_{6}$ (sodium tetra thionate) 용액이었으며, 용액은 농도조건을 맞 추기 위해 저항이 $18 \mathrm{M} \Omega \mathrm{cm}$ 정도의 순수를 사용하여 제조하였고 고순도 질소를 사용하여 1 시간 정도 탈기 (purging)하여 용존 상태의 산소 등 기체를 제거한 후 부식 실험을 수행하였다. 온도조건은 상온이었으며, 대기압에서 침지실험이 수행되었다. 부식실험용기는 자체 제작한 것으로 기밀성을 보장하기 위해 누설시 험으로 실험 중 공기의 유입이 전혀 없음을 확인하였 고, Fig. 3은 아크릴로 제작된 침지실험용 부식시험용 기를 보여준다. 이 시편들은 아크릴로 제작된 상온 응력부식균열 시험용 용기에 장입된 후 일정시간의 경과에 따라 인출하여 표면관찰 및 와전류탐상시험에 의한 균열 발생여부를 확인하고 균열발생 시편들에 대해 파괴시험을 수행하였다.

\section{3. 결과 및 고찰}

3-1. 응력부식균열 발생유무 확인

확관방법에 따라 각기 제작된 전열관 시험편에 응

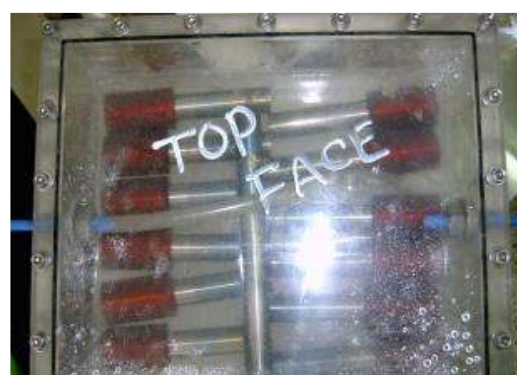

Fig. 3. Acrylic container used in immersing test for stress corrosion cracking at room temperature.

력부식균열을 발생시키기 위한 상온 침지시험과 전열 관 시편의 내면에 대한 균열 발생여부를 확인하기 위 해 6시간, 12 시간, 24 시간, 48 시간, 72 시간 그리고 96 시간마다 모터구동 회전형탐촉자(motorized rotating pancake coil)를 사용하여 와전류탐상시험이 수행되 었다. 시험을 위해 준비된 시편들은 다음과 같다.

- 관판재질로 SA $508 \mathrm{Cl} .3$ 탄소강이 사용된 확관부 시편

- 정상적 폭발확관 시편: 3 개

- 과확관된 폭발확관 시편: 3 개

- 정상적 수압확관 시편: 3 개

- 과확관된 수압확관 시편: 3 개

※ 부식시험 중 탄소강 관판은 제거한 후 시험됨.

- 관판재질로 304 스테인리스강이 사용된 확관부 시편

- 정상적 폭발확관 시편: 4 개

- 과확관된 폭발확관 시편: 4개

- 정상적 수압확관 시편: 4개

- 과확관된 수압확관 시편: 4 개

Table 1-(a)는 탄소강 관판을 가지고 각각 정상 및 과확관 상태가 되도록 폭발확관 및 수압확관된 전열 관 시편들의 주기별 와전류탐상시험 결과로서 수압확 관의 경우 균열발생율이 폭발확관보다 다소 높았다. Table 1-(b)는 스테인리스강 관판을 가지고 각각 정 상 및 과확관 상태가 되도록 폭발확관된 전열관 시편 들의 주기별 와전류탐상시험 결과인데 과확관의 경우 균열발생율이 정상확관보다 다소 높았다. Table 1-(c) 는 스테인리스강 관판을 가지고 각각 정상 및 과확관 상태가 되도록 수압확관된 전열관 시편들의 주기별 와전류탐상시험 결과로 모든 시편에 균열이 발생한 것을 확인하였으며, 특히 침지 후 24시간 만에 모든 
Table 1. Eddy current test results of specimens during immersion test: a) with carbon steel tubesheet, b) expanded explosively with stainless steel tubesheet, c) expanded hydraulically with stainless steel tubesheet.

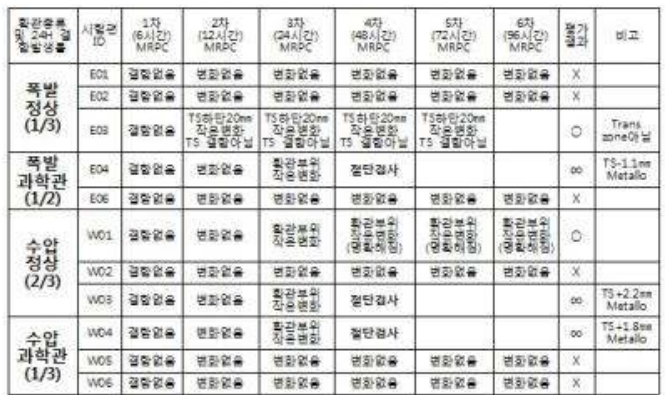

(a)

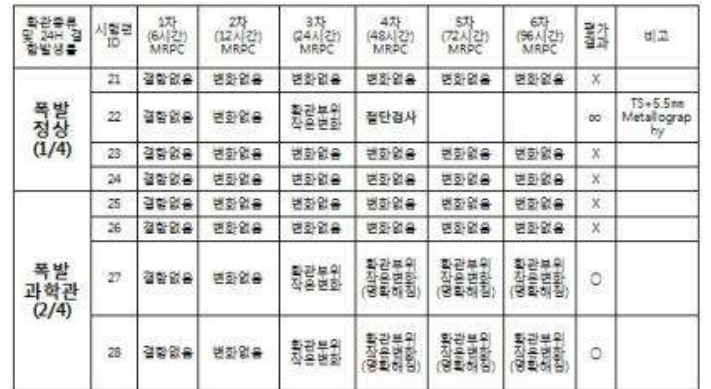

(b)

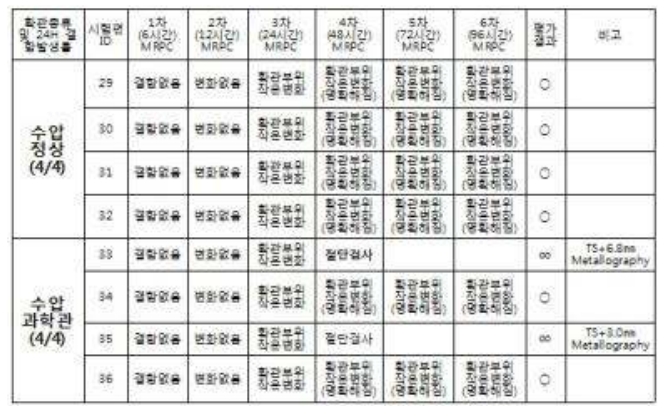

(c)

시편이 균열 개시 징후를 보였다. Table 2에 와전류 탐상시험과 파괴시험을 통해 균열발생이 확인된 시편 들의 균열발생율을 종합적으로 요약하였으며 확관방 법에 따른 차이로서 수압확관에서 균열 발생율이 더 높은 것으로 나타났다. 앞서 설명하였듯이 스테인리 스강 관판을 가지고 수압확관된 경우 24시간의 부식 시험에서 $100 \%$ 균열 발생을 확인할 수 있었다. 탄소 강 관판을 가진 수압확관의 경우에서도 결함발생율은 높은 것으로 나타났다. 와전류탐상시험과 파괴검사의 차이를 살펴보면 와전류탐상시험으로는 검출되지 않 은 균열이 많이 있는 것으로 나타났고, 파괴검사 시 와전류탐상시험으로 결함이 검출되지 않는 시편도 균 열이 발견된 경우가 있었다.

\section{3-2. 파괴검사를 통한 균열길이/방향 분석}

균열이 발생된 각 시편에 대해 파괴검사를 통해 균 열길이 및 방향에 대한 통계적인 분석을 수행하였다. 계산되는 균열의 기준을 정하기 위해 아래와 같은 판 단기준을 세워 데이터를 처리하였다.

- 균열의 길이가 $1 \mathrm{~mm}$ 이상인 경우만 균열로 간주

- 축방향과 원주방향으로 분류하여 각 균열의 길이 를 측정
Table 2. Summary of crack initiation rate for all specimens tested by eddy current test and destructive examination

\begin{tabular}{|c|c|c|c|c|c|c|c|c|c|c|}
\hline & \multirow{2}{*}{ 항를 } & \multirow{2}{*}{ 管臂 } & \multirow{2}{*}{ 와란 $=4$} & \multicolumn{6}{|c|}{ 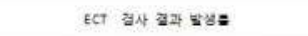 } & \multirow{2}{*}{ 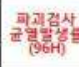 } \\
\hline & & & & $6 \mathrm{H}$ & $12 H$ & $24 \mathrm{H}$ & 495 & $72 H$ & 969 & \\
\hline \multirow{4}{*}{$\begin{array}{l}\text { SA } \\
50 \mathrm{~B} \\
\text { TS }\end{array}$} & \multirow{2}{*}{ 팩팔 } & Norrmal & $23 \div 26$ & $0 / 3$ & $1 / 3$ & $1 / 3$ & $1 / 3$ & $1 / 3$ & $1 / 3$ & $3 / 3$ \\
\hline & & Ovort +3nn & $23-27$ & 0,2 & $0 / 2$ & $1 / 2$ & $1 / 2$ & $1 / 2$ & $1 / 2$ & $2 / 2$ \\
\hline & \multirow{2}{*}{ 수안 } & $\begin{array}{l}\text { Normal } \\
(\$ 2000)\end{array}$ & $21 \sim 24$ & $0 / 3$ & $0 / 3$ & $2 / 3$ & $2 / 3$ & $2 / 3$ & $2 / 3$ & $1 / 3$ \\
\hline & & (Oves) & $19-23$ & $0 / 3$ & $0 / 3$ & $1 / 3$ & $1 / 3$ & $1 / 3$ & $1 / 3$ & $3 / 3$ \\
\hline \multirow{4}{*}{$\begin{array}{c}\text { SS } \\
304 \\
\text { TS }\end{array}$} & \multirow{2}{*}{ \#s: } & Normal & $222 \% 35$ & $0 / 4$ & $0 / 4$ & $1 / 4$ & $1 / 4$ & $1 / 4$ & $1 / 4$ & $4 / 4$ \\
\hline & & Over+3ns & $23-3.4$ & $0 / 4$ & $0 / 4$ & $2 / 4$ & $2 / 4$ & $2 / 4$ & $2 / 4$ & $4 / 4$ \\
\hline & \multirow{2}{*}{$=ㅇ ㅏ ㅇ$} & $\begin{array}{l}\text { Normal } \\
(32000)\end{array}$ & $29-44$ & $0 / 4$ & $0 / 4$ & $4 / 4$ & $4 / 4$ & $4 / 4$ & $4 / 4$ & $4 / 4$ \\
\hline & & $\begin{array}{l}\text { Over } \\
(35000)\end{array}$ & $26-31$ & $0 / 4$ & $0 / 4$ & $4 / 4$ & $4 / 4$ & $4 / 4$ & $4 / 4$ & $4 / 4$ \\
\hline
\end{tabular}

- 기울어진 경우, 축방향과 원주방향으로 분해하여 각각 처리

- 총 균열수, 평균 균열길이, 총 균열길이 등을 계산

- 확관 조건별 및 방법별 평균치 계산

Fig. 4는 확관조건에 따른 총 균열길이, 균열 수 그 리고 평균 균열길이를 비교한 것이다. 총 균열길이의 경우, 수압확관된 시편들에서 원주방향의 총 균열길 이가 증가되었고, 폭발확관된 시편들에서는 축방향의 총 균열길이가 증가함을 알 수 있다. 균열 수의 경우 도 수압확관의 경우에서 원주방향의 균열 수가 증가 
한 반면에 폭발확관의 경우에는 축방향의 균열 수가 증가하고 있다. 최대 균열길이의 경우도 수압확관 시 편들에서 원주방향 균열의 길이가 높게 나타나고 있 으며, 폭발확관 시편들에서는 축방향의 균열길이가 높음을 알 수 있다. Fig. 5-(a)는 확관조건에 따른 원 주방향 균열들을 비교한 것이다. 그림에서와 같이 원 주방향 균열의 수, 최대길이, 총 균열길이 모두 폭발 확관에 비해 수압확관한 경우 증가하였다. 이와는 반 대로 Fig. 5-(b)는 확관조건에 따른 축방향 균열들을 비교한 것으로 축방향 균열의 수, 최대길이, 총 균열 길이 모두 수압확관에 비해 폭발확관한 경우 증가한 것을 알 수 있다. Fig. 6-(a)와 (b)는 폭발확관 및 수 압확관에 따른 원주방향 균열과 축방향 균열의 특성 을 각각 비교한 것이다. 수압확관은 원주방향 균열의 수, 최대 균열길이, 총 균열길이, 평균 균열길이 모두 증가하는 경향을 보였다. 반면에 축방향 균열의 경우 는 모든 특성이 감소하는 경향을 보였다. 특히 각 확

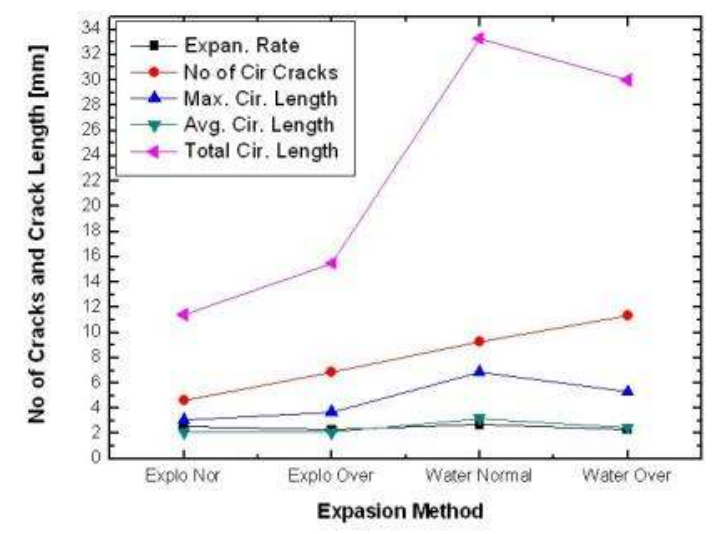

(a)
관법에서 우세한 방향의 균열 수, 평균 균열길이, 총 균열길이가 증가하는 현상을 나타내는 이유는 수압확 관의 경우 천이영역에서 길이방향의 변형을 증가시키 는 반면에 폭발확관은 확관부 및 천이영역에서 원주

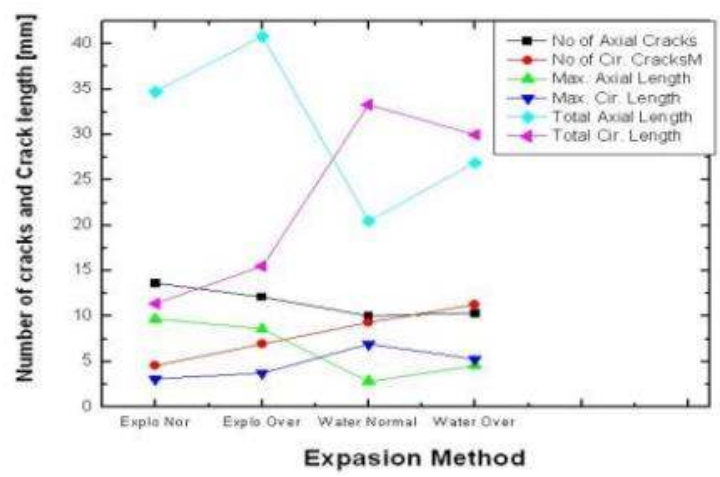

Fig. 4. Comparisons of total crack length, number of cracks, and average crack length due to expansion conditions.

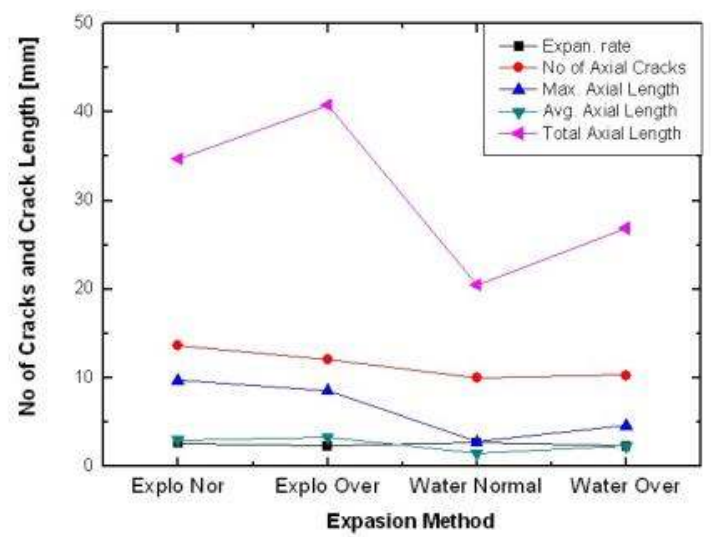

(b)

Fig. 5. Comparisons of cracks due to expansion conditions: a) with circumferential direction and b) with axial direction.

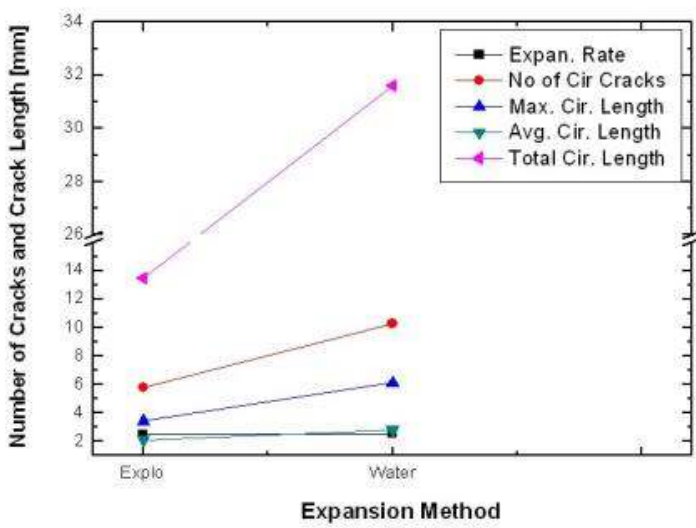

(a)

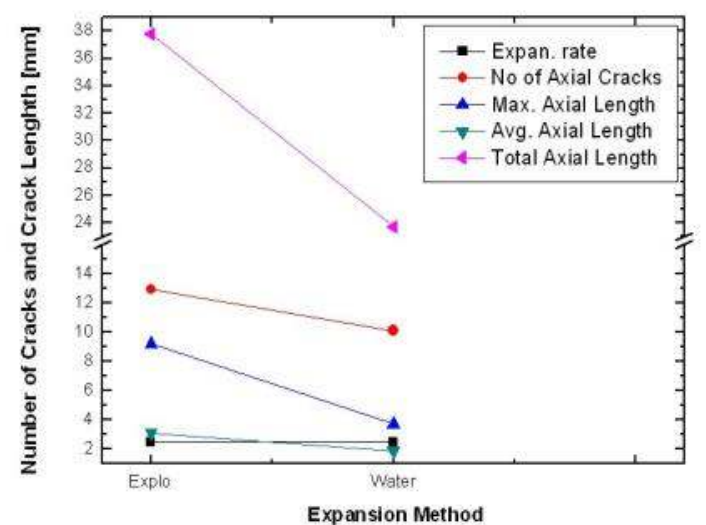

(b)

Fig. 6. Comparisons of cracks due to explosive/hydraulic expansion: a) with circumferential direction and b) with axial direction. 
방향의 변형을 증가시키는 고유 확관특성을 갖기 때 문인 것으로 추정된다.

모든 전열관 시편 표면 위에서 균열 형상을 관찰한 결과, 축방향 균열이 상대적으로 넓은 범위에 걸쳐서 형성되는 것에 비하여, 원주방향 균열의 형성 위치가 국부적인 곳에 한정되어 존재하는 이유는 천이 영역 에서 국부적인 변형의 불연속점이나 국부적인 잔류응 력이 형성되기 때문으로 보인다. 일반적으로 천이 영 역에서 응력부식균열 형성이 집중되는 이유는 선행 연구로서 수행된 잔류응력 측정결과에서도 알 수 있 듯이 천이 영역에 형성된 잔류응력 때문이다[3]. 이를 측정하기 위하여 사용되는 X-ray나 스트레인 게이지 측정법은 일정한 면적의 평균값을 측정할 수밖에 없 으므로 국부적인 잔류응력 천이현상을 발견할 수는 없어 생성될 균열의 방향 등 특성을 예견하는 것이 힘들 것이라 판단된다. 본 연구의 목적으로 규명코자 했던 잔류응력 특성과 응력부식균열의 발생 정도 및 방향성과의 상관관계를 일목요연하게 설명하는 것은 힘들어 보인다. 실험실에서의 응력부식균열 시험은 폭발확관에서는 축방향 균열 그리고 수압확관에서는 원주방향균열이 우세하게 나타난 반면에 실제 발전소 현장에서의 균열 발생 양상은 그 정반대이다. 물론 본 응력부식균열 실험에서 반영되지 못한 한 가지 요 소로서 원전 현장에서는 균열을 가진 대부분의 전열 관들에 덴트라는 아주 작은 국부적인 변형이 함께 검 출되는데 인위적으로 덴트를 발생시키면서 응력부식 균열 시험을 모사하는 것은 극히 어렵다.

Flesch 등은 FEM 해석을 통해 Fig. 7에서와 같이 슬러지가 있는 경우 전열관의 외면에서는 인장잔류응 력이 압축잔류응력으로 변하고, 전열관의 내면에서는 압축잔류응력이 인장잔류응력으로 변할 수 있다고 보 고하였다[5]. 이와 같이 잔류응력을 측정하는 것은 시 험을 통해서나 해석을 통해서나 극히 어려운 작업이 라고 생각된다. 실제 원전 현장에서와 같이 슬러지가 있는 상태에서 덴트가 발생하면 다중응력 발생원에 의해 압축잔류응력이 인장잔류응력으로 변형되는 것 은 응력부식균열 발생 실험실 시험결과와 원전 현장 에서 나타나는 균열발생형태의 차이에 대한 해석 가 능성을 제시한다고 생각된다. 즉, 전열관의 확관 시에 는 대체로 압축응력이 우세하게 전열관에 남아 있으 나 가동연수가 증가함에 따라 덴트가 발생하고 이 덴 트는 전열관 내·외면의 잔류응력을 변화시켜 균열의 발생을 용이하게 하는 것으로 추정된다. 이와 같은
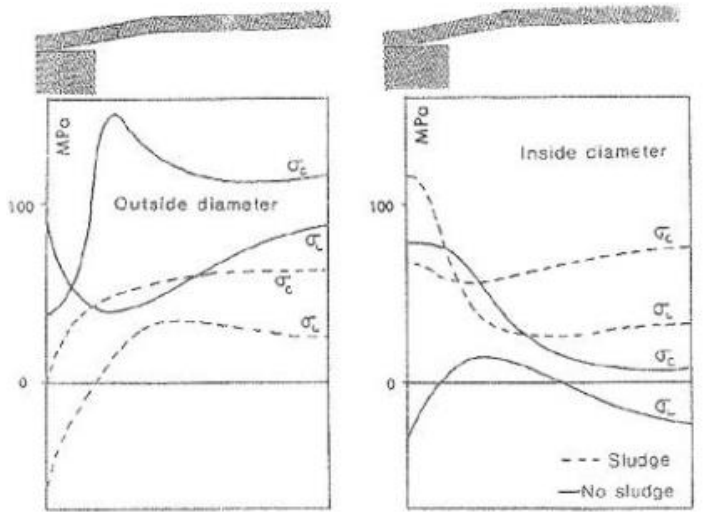

Fig. 7. Stress evolution along the tube in steady state power operation.

현상은 1990년대 초에 수압확관 방식으로 확관된 전 열관을 가진 고리 2호기에서 관판상단 확관천이부위 에 축방향의 균열이 발생했을 때, 균열 발생세관들은 모두 덴트가 같이 발생하였으며, 인출세관 검사결과 에서도 원주방향균열 징후가 확인 되었었다는 사실과 도 관계가 있다고 판단한다[6]. 또한 $\mathrm{Han}$ 등의 보고 에 따르면, 이 경우 폭발확관은 확관 시의 확관천이 부위 변형으로 수압확관 보다 틈새의 형성 가능성이 높아 덴트가 월등하게 잘 발생한다[7]. 다만 덴트의 발생으로 인한 전열관 표면 잔류응력의 방향 및 분포 가 변하는 것에 대해서는 향후 더 정밀하고 정교한 검증 해석과 연구로 풀어야 할 숙제다.

\section{3-3. 파단면 관찰}

균열의 특성을 알기 위해 응력부식균열 시험을 통 해 원주방향 균열이 발생한 폭발확관된 전열관 시편 을 주사전자현미경으로 관찰하였다. 조직관찰과 함께 $\mathrm{EDX}$ 를 사용하여 파단면의 입구와 균열 선단지역에 대한 성분분석을 수행하였다. Fig. 8은 폭발 확관된 시편의 내면에서 발생한 원주방향 균열을 보여준다. 원주방향 균열은 주 균열과 함께 수많은 작은 균열들 이 내면에 발생해 있는 것을 알 수 있다. 이 작은 균 열들은 시편 관찰 초기에는 나타나지 않았으나 시편 을 축방향에서 구부림에 따라 명확히 나타났다. 이렇 게 많은 작은 균열들이 생성된 것은 균열의 조기발생 을 유도하기 위해 시험전 시편에 수행한 예민화 처리 의 효과가 컸을 것으로 생각된다. 또한 주 균열에 인 접한 작은 균열도 관찰되었으며 전형적인 입계균열 형태를 보여준다. Fig. 9는 원주방향 주 균열의 파단 

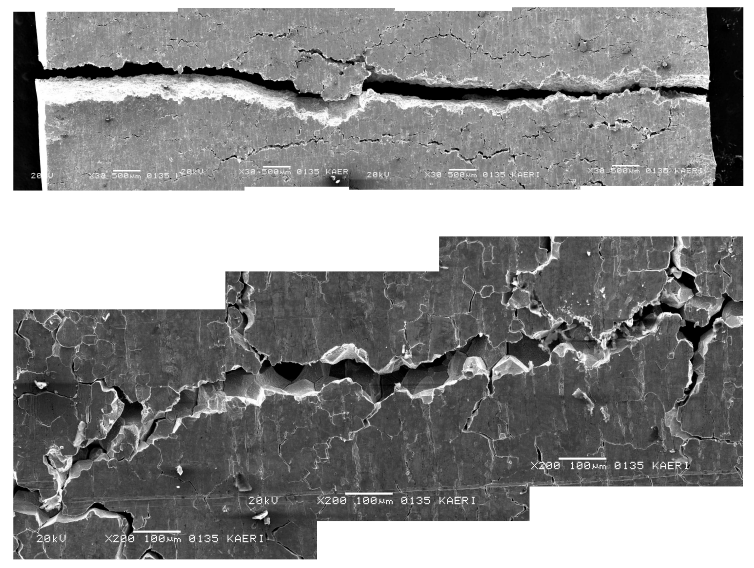

Fig. 8. A ID small circumferential crack near the main crack of specimen expanded explosively.
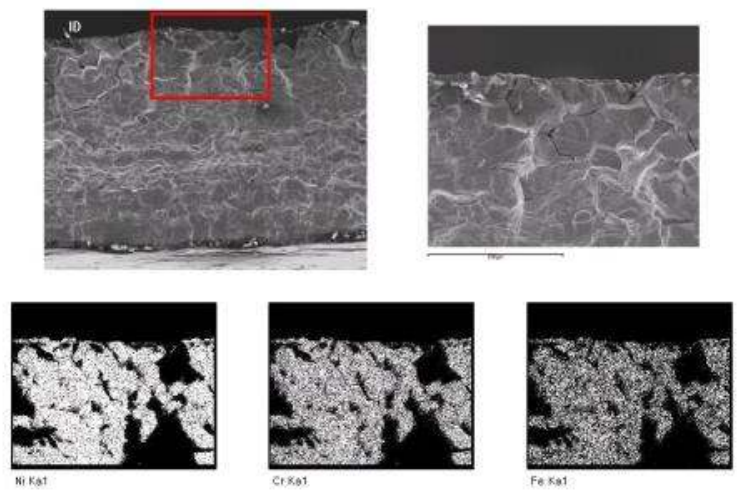

Fig. 10. EDX analyses of crack opening area of specimen expanded explosively in Fig. 8.

면을 관찰한 사진이다. 균열형태가 전형적인 입계균 열임을 알 수 있고 시편의 외면 쪽 빨간 선으로 표시 한 지역은 밴딩에 의해 절단될 때 뜯겨져 나간 부분 이다. Fig. 10은 균열 입구에 대한 $\mathrm{EDX}$ 분석 결과이 다. 모재인 Alloy 600 의 주요 구성원소로서 니켈, 크 롬, 철이 주된 성분임을 보여준다. Fig. 11은 그 외에 균열에 영향을 주었을 것으로 짐작되는 원소인 황, 칼슘, 인, 알루미늄, 칼륨, 구리, 티타늄을 분석항목으 로 잡아 분석하였는데 황을 비롯하여 각 원소들이 미 량 존재하는 것으로 나타났다.

이 같은 분석결과는 $\mathrm{Han}$ 등에 의해 영광 4 호기의 인출 전열관에 대한 분석 시 알루미늄, 칼슘, 황, 칼 륨, 인 등이 검출되었다고 하는 결과와 유사하다[7]. 나트륨, 마그네슘 등의 양이온을 함유한 황산염 형태 로서 황은 특정한 원소로서가 아닌 단지 $\mathrm{pH}$ 에 미치

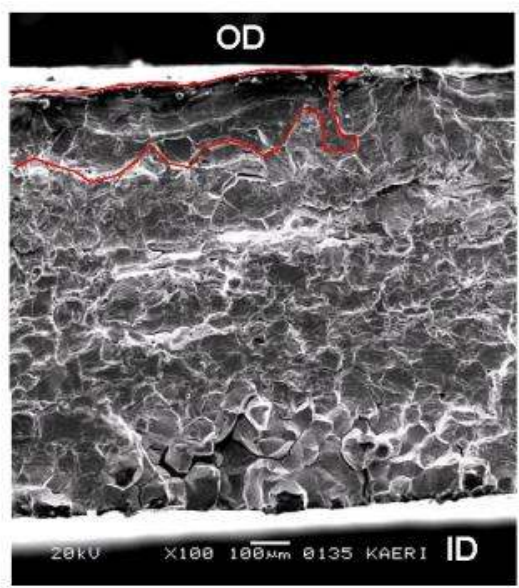

Fig. 9. Crack area and non-crack area of specimen expanded explosively in Fig. 8.
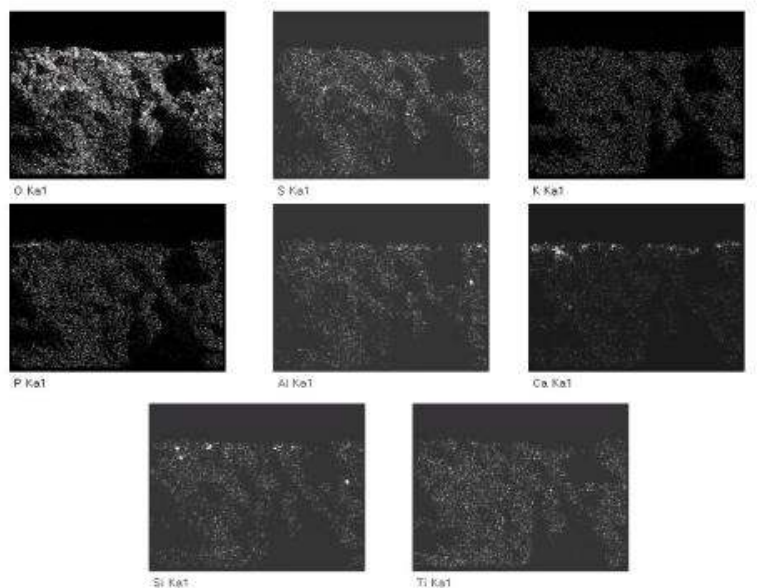

Fig. 11. Other EDX analyses of crack opening area of specimen expanded explosively in Fig. 8

는 영향으로 전열관 재료의 입계부식/입계응력부식균 열에 영향을 미치는 것처럼 보인다. 그러나 만약 황 이 낮은 산화상태, 즉 환원상태에 존재하면, 황은 특 정 화학종으로서의 영향을 갖는 것처럼 보인다. 환원 된 황은 니켈 표면에서 부동태막의 형성을 방해하며, 이 막들의 깨짐을 돕는 것 같다. Berge는 환원된 황 성분이 분명 Alloy $600 \mathrm{SR}$ 과 같은 예민화된 재료의 입계응력부식균열을 강하게 가속시키는데, 그 이유는 입계에서의 크롬 결핍이 입계에서 막을 부식에 더욱 민감하도록 만들기 때문이라고 설명했다[8]. 한편 Harper 등은 이 형태의 부식은 단지 약 $100^{\circ} \mathrm{C}$ 미만의 온도에서 작동하는 것을 확인했다고 보고한 바 있다 [9]. 더욱 일반적으로 환원된 황 성분은 예민화되지 않은 재료의 재부동태화(repassivation)를 방해하는 것처럼 보이며, 모재합금을 염기성 및 중성 환경에서 
더욱 잘 부식되도록 만든다. Combrade 등에 따르면 황의 효과는 모재 합금에서 크롬의 농도가 증가함에 따라 감소하는 것처럼 보인다[10]. Cullen 등에 의하 면 시험들은 산성 황산염이 열처리 조건과는 무관하 게 Alloy 600과 Alloy 690의 웨이스티지를 일으킬 수 있음을 보여 주었다[11]. 황산염-염화물 복합계에 서 주어진 $\mathrm{pH}$ 에서의 웨이스티지는 황산염의 분율이 증가함에 따라 증가하고, 반면에 $100 \%$ 염화물 용액 에서는 웨이스티지가 거의 일어나지 않는다. 균열 선 단에 대한 $\mathrm{EDX}$ 분석결과도 균열 입구에서의 분석결 과와 유사하게 황이 다른 원소에 비해 많이 검출되었 으며 이를 근거로 균열의 개시 및 성장에 황이 주요 역할을 했을 것으로 생각된다.

\section{4. 결론}

폭발확관 및 수압확관된 전열관 시편에 대한 응력 부식균열실험 수행 및 파단면을 관찰한 결과 다음과 같은 결론을 얻었다.

가. 폭발확관은 축방형 균열에 대해, 수압확관은 원주방향 균열에 대해 우세한 발생경향을 갖 는 것으로 나타났다.

나. 수압확관의 경우는 천이영역에서 길이방향의 변형을 증가시키는 반면에 폭발확관은 확관부 및 천이영역에서 원주방향의 변형을 증가시키 는 고유 확관특성을 갖는 것처럼 보인다.

다. 균열 발생위치를 관찰한 결과, 축방향 균열이 상대적으로 넓은 범위에 걸쳐서 형성되는 것 에 비해 원주방향 균열의 형성 위치는 국부적 인 곳에 한정되어 발생했다.

라. 폭발확관의 경우, 응력부식실험 결과로서 우세 한 축방향 균열 발생현상이 나타난 것은 잔류 응력 측정결과와 대체로 일치하지만, 실제 발 전소에선 원주방향 균열의 발생이 우세하다. 그 이유로는 균열과 함께 검출되는 덴트로 인 해 잔류응력의 성질이 압축응력에서 인장응력 으로 바뀌었기 때문인 것으로 판단된다.

마. 파단면 관찰결과, 균열 형태는 전형적인 입계 균열임을 확인하였다.

바. 부식용액으로 사용된 $\mathrm{Na}_{2} \mathrm{~S}_{4} \mathrm{O}_{6}$ (sodium tetra thionate) 중의 황이 균열 입구와 선단에서 동 시에 발견되었으며 황이 균열의 개시와 전파 에 가속인자로서 작용했음을 알 수 있다.

\section{후기}

이 논문은 2014학년도 홍익대학교 학술연구진흥비 에 의해 지원되었습니다.

\section{References}

1. 홍준화, 원자력재료, 한스하우스, 2012, 524-527

2. Young Kyu Kim, Myung Ho Song and Myung Sik Choi, A study on the Profile Change Measurement of Steam Generator Tubes with Tube Expansion Methods, J. of KSNT, Vol.31 No.5, 2011, 543-551

3. 김용규, 송명호, 원전 증기발생기 전열관 확관법 이 확관부위 잔류응력에 미치는 영향, 에너지공 학, 제 21 권 제4호, 2012, 362-372

4. 김용규, 송명호, 유완, 한국표준형원전 증기발생 기 전열관 확관부위의 응력해석, 에너지공학, 제22권 제2호, 2013, 1-8

5. B. Flesch, P. Vidal, D. Buisine, and B. Cochet, Operating Stresses and Stress corrosion cracking in Steam Generator Transition Zones (900-MWe PWR), SMiRT 11 Transactions Vol. F, Tokyo, Japan, 1991, 371-376

6. 김우철 등, 고리 2 호기 증기발생기 전열관 인출 검사 - 최종보고서, 한국원자력연구소, 1992, 7-14

7. 한정호 등, 영광4호기 증기발생기 전열관 인출 검사 및 분석, KAERI/CR-168, 한국원자력연구 소, 2003, 8-16

8. J. P. Berge, Evaluation of Residual Tensile Stresses by Accelerated Stress Corrosion Cracking tests, Workshop Proceedings: U-Bend Tube Cracking in Steam Generator, EPRI-WS-80136, 1981

9. S. Harper, et al., The Role of Sulfur in the Corrosion of NSG, Proceedings of the Third International Symposium on Environmental Degradation of Materials in Nuclear Power Systems-Water Reactors, TMS, 1988, 457-463 10. P. Combrade, et al., Effect of Sulfur on the Protective Layers of Alloy 600 and 690 in 
Low and High Temperature Environments,

Proceedings of the Fourth International Symposium on Environmental Degradation of Materials in Nuclear Power Systems-Water Reactors, NACE, 1990, 5-79 5-95

11. W. H. Cullen and M. J. Partridge, Susceptibility of Alloys 600 and 690 to Acidified Sulfate and Chloride Environments, EPRI TR-104045, 1994 